\title{
PATH ANALYSIS ON THE ASSOCIATION BETWEEN PREDISPOSING, ENABLING, AND REINFORCING FACTORS, AND HOUSE SANITATION IN BENGKULU, SUMATERA
}

\author{
Shinta Nasir ${ }^{1)}$, Bhisma Murti ${ }^{1)}$, Nunuk Suryani²) \\ 1)Masters Program in Public Health, Sebelas Maret University \\ 2)Faculty of Teaching and Educational Sciences, Sebelas Maret University
}

\begin{abstract}
Background: Poor sanitation is one of the primary causes of communicable diseases in the world. According to UNICEF (2012) 116 million people in Indonesia in 2010 were lacking in standard sanitation. In Bengkulu province, only $33.18 \%$ household in 2014 and $39.22 \%$ in 2015 had access to good sanitation. This coverage was lower than that of the national level at $62.14 \%$. This study aimed investigating the association between predisposing, enabling, and reinforcing factors, and house sanitation in Bengkulu, Sumatera.

Subjects and Method: This was an analytic and observational study with cross sectional design. This study was conducted in Teluk Segara District, Bengkulu, Sumatera from November to December 2016. A total of 120 households were selected by fixed exposure sampling for this study. The dependent variable was household sanitation. The independent variables were family education, family income, health education, social capital, and health behavior. The data were collected by a set of questionnaire and analyzed by path analysis.

Results: Family education $(b=1.08 ; \mathrm{SE}=0.48 ; \mathrm{p}=0.024)$ and health education $(b=0.19 ; \mathrm{SE}=0.07 ; \mathrm{p}=0.007)$ had positive and statistically significant effect on household sanitation. Health education had positive and statistically significant effect on healthy behavior $(b=0.09 ; \mathrm{SE}=0.04 ; \mathrm{p}=$ 0.018). Social capital had positive and marginally significant effect on healthy behavior $(b=0.05 ; \mathrm{SE}=0.03 ; \mathrm{p}=0.099)$. Family income $(\mathrm{b}=0.14 ; \mathrm{SE}=0.45$; $\mathrm{p}=0.756)$ and family education $(\mathrm{b}=0.15 ; \mathrm{SE}=0.25 ; \mathrm{p}=0.566)$ did not show significant effect on household sanitation.

Conclusion: Family education and health education had positive and statistically significant effect on household sanitation. Health education had positive and statistically significant effect on healthy behavior. Social capital had positive and marginally significant effect on healthy behavior. Family income and family education did not show significant effect on household sanitation.
\end{abstract}

Keywords: path analysis, predisposing, enabling, reinforcing factors, household sanitation

Correspondence: Shinta Nasir. Masters Program in Public Health, Sebelas Maret University, Jl. Ir. Sutami 36 A, Surakarta 57126, Central Java, Indonesia. Email: shinta_nasir26@yahoo.co.id. 